\section{Сабина Ђуркић}

Библиотека „Центар за културу”, Кладово

sabina.djurkic@gmail.com
Стручни рад

UDK 025.22(497.11)"2010/2019"

021.9(497.11)"2010/2019"

https://doi.org/10.18485/bibliotekar.2019.61.2.3

\title{
ОТКУП КЊИГА У МАЛИМ БИБЛИОТЕКАМА: У РАСКОРАКУ СА ПОТРЕБАМА КОРИСНИКА
}

Сажетак: Библиотека у Кладову, поред само три библиотеке у Србији, од 2010. године има и свој библиобус. Деца до 14 година чине 95\% корисника у библиобусу. Грађа коју највише користе и која им је најпотребнија припада дечјој књижевности. Откуп публикација Министарства културе и информисања Републике Србије био је до сада веома значајан вид набавке књига за кориснике библиобуса, али овогодишњи откуп то није. Одобрени буџет за библиобус сада је свега $1 \%$ одобреног буџета за библиотеку, а некада је износио и до 50\%. У 2019. години за библиобус је наручено само 6 књига, док све остале добијене књиге представљају обавезне наслове. Овај рад показује зашто садашњи модел откупа апсолутно није погодан за мање библиотеке, односно библиобусе, и да би могућност да библиотекари сами бирају наслове, уз евентуално саветодавну улогу стручне комисије, сигурно допринела бољем и ефикаснијем откупу.

Кључне речи: јавна библиотека, библиобус, корисници библиотека, откуп књига, обавезни наслови.

\section{Увод}

Библиотеке постоје и функционишу у различитим срединама, али за све је заједничко да „постоје да би служиле својим корисницима”. ${ }^{1}$ Притом, подразумева се да служе свим корисницима, иако се они разликују по узрасту, полу, образовању, менталним способностима... Успешност у раду

Piter Klejton i Gari Judžin Gorman, Upravljanje izvorima informacija u bibliotekama (Beograd:

Clio, 2003), 12. 
једне библиотеке манифестује се кроз испуњавање потреба најширег круга корисника или, другачије речено, сматра се да „задовољавање потреба корисника остаје суштина библиотечких услуга”.

Приликом набавке књига за једну библиотеку треба поступати одговорно и промишљено, односно „ускладити квалитет и квантитет, уједначити набавку са степеном коришћења фонда, помирити је са издавачким политикама, уважити жеље корисника и поставити границе у тривијализацији фонда"з. Ипак, можемо рећи да на набавну политику и сам процес набавке нових књига, како у јавним библиотекама, тако и у свим другим типовима библиотека, највећи утицај имају корисници и њихове читалачке потребе и да се библиотекари најчешће руководе максимом да „задовољење потреба корисника јесте потврда библиотекару на набавци да тај посао добро ради"4. То подразумева да сваки библиотекар који обавља послове набавке мора бити добро информисан о категоријама својих корисника и њиховим потребама, о статусу и структури библиотечких фондова, као и да редовно прати издавање нових публикација.

\section{Библиобус у Кладову}

Библиотека „Центра за културу” Кладово једна је од четири библиотеке у Србији, поред Пријепоља, Алексинца и Крушевца, која има свој библиобус, односно покретну библиотеку. Библиобус је 2010. године стигао у Кладово као поклон француског Департмана Вандеје. Реч је о савремено опремљеном Iveco камиону произведеном 2001. године, у чијем се простору величине $18 \mathrm{~m}^{2}$ налазе полице за књиге у дужини од $50 \mathrm{~m}$. Капацитет библиобуса је до пет хиљада библиотечких јединица.

Поседовати библиобус данас представља велику привилегију, како за библиотеку, тако и за саму општину. Библиобус доприноси не само развоју културног идентитета установе на територији целог краја, већ омогућава и лични развој већег броја појединаца кроз додатно образовање и информисање. Међутим, библиобус такође представља и велику обавезу која захтева додатна финансијска средства за гориво, текуће одржавање возила, сервисирање, гаражни простор... Ипак, захваљујући библиобусу, наша биб-

Piter Brofi, Biblioteka u dvadeset prvom veku (Beograd: Clio, 2005), 115.

Гордана Стокић Симончић, „Библиотеке и издавачи”, Чийалишиее год. 14, бp. 27 (2015): 1.

4 Nevenka Perunović, Principi nabavne politike u bibliotekama (Beograd: Zadužbina Andrejević, 1997), 11. 
лиотека је у могућности да пружање својих библиотечко-информационих услуга прошири до свих крајева општине Кладово и стигне до бројних удаљених корисника, пре свега до сваког детета, зато што су, за сада, свих 12 стајалишта покретне библиотеке у селима поред основних школа.

Структура корисника библиобуса је таква да 95\% корисника чине деца до 14 година (предшколски и основношколски узраст), а око 5\% представљају одрасли корисници, углавном учитељи и наставници. Сходно томе, грађа која се највише користи у библиобусу спада у дечју литературу и обухвата популарне наслове за децу и тинејџере, стрипове и сликовнице. Сва та грађа се пажљиво бира и редовно мења и допуњује новим насловима. Од самог почетка рада библиобуса трудили смо се да његов књижни фонд прилагодимо корисницима. Прво је библиобус био опремљен већим бројем књига за децу, које су представљале вишак на дечјем одељењу библиотеке, али такође и мањим бројем квалитетних наслова домаће и преведене књижевности с одељења за одрасле, а касније су се, приликом сваке куповине књига за библиотеку, куповале и књиге за библиобус и када су се набављали актуелни дечји наслови. Због обиласка корисника по циклусима (на сваке две недеље), нови наслови су куповани у више примерака да би могла да их позајме деца из свих насеља.

\section{Откуп књига за библиобус}

Значајан вид набавке књига за све јавне библиотеке је откуп публикација Министарства културе и информисања Републике Србије путем којег држава, издвајајући одређена финансијска средства, откупљује књиге од издавача, које се потом дистрибуирају библиотекама. За мрежу јавних библиотека откуп представља сасвим сигурно велику подршку, а за многе библиотеке је, нажалост, веома често и једини начин набавке нових књига, због тога што су средства оснивача за куповину књига недовољна или чак потпуно изостају.

На иницијативу Народне библиотеке Србије, од 2010. године библиотека у Кладову, поред откупа књига за са̂му библиотеку, преко откупа Министарства културе и информисања добија и књиге за библиобус. У протеклих десет година, мада би тачније било рећи у првих седам година, колико се откупљују књиге за библиобус, корисницима наше покретне библиотеке откуп је пружио већу и атрактивнију понуду наслова, тј. изразито је побољшао књижни фонд библиобуса, чиме је олакшао библиотекарима промовисање добрих и квалитетних књига, ојачао наш утицај на форми- 
рање одговарајућег књижевног укуса младих корисника. Актуелна грађа, коју дефинишу одабрани нови наслови и довољан број примерака, допринела је повећању читалачке популације у нашој покретној библиотеци.

Нажалост, од 2017. године, када је стручна комисија за откуп први пут увела обавезне наслове, деци - готово јединим корисницима библиобуса, достављена су бројна уско профилисана дела теоријског карактера, унапред намењена малом броју корисника, која притом спада искључиво у књижевност за одрасле. А то је у потпуној супротности са речима некадашњег председника Комисије за откуп књига за библиотеке, Милана Влајчића, који је 2015. године, на скупу одржаном у Градској библиотеци Панчево, о могућности да комисија сама бира наслове за библиотеке рекао следеће: „Не знам која би комисија имала храбрости, грађанске и моралне, да пробере књиге унутар предвиђеног буџета. То би био апсолутизам без преседана” и то образложио, између осталог, речима: „зашто неким библиотекама у мањим местима наметати теоријска дела за која оне немају радознале читаоце"

\section{Одобрени бущет}

Буџет који је од стране Министарства културе и информисања био одобрен библиобусу за откуп књига варирао је током протеклих десет година, али је у сваком случају најчешће значајно доприносио повећању укупног буџета библиотеке за набавку нових књига. За период од 2010. до 2014. године одобрени буџет нашој библиотеци увећан је за скоро 50\%, тј. толико је процентуално представљао буџет за откуп публикација намењених библиобусу наспрам буџета за библиотеку. У 2015. и 2016. години то повећање је смањено и износило је око 35\%. Са увођењем обавезних примерака у 2017. години, као и извршеној категоризацији јавних библиотека и сврставањем наше библиотеке у 3. категорију, а библиобуса у 1. категорију, одобрени буџет за библиобус драстично је смањен - 2017. године износио је $17 \%, 2018$. године $15 \%$, док је ове, 2019. године, износио свега $1 \%$. Тачније, за библиобус смо ове године могли да наручимо књиге у вредности од 2.424,03 динара, што је било довољно за само шест књига, а све остале добијене књиге биле су обавезни наслови! Поређења ради, највећи буџет

5 „Набавна политика библиотека и спровођење откупа публикација за библиотеке Министарства културе и информисања Републике Србије”, Чийалишиее год. 14, бр. 27 (2015): 42. 
за самостално наручивање књига за библиобус био нам је одобрен 2014. године и износио је 240.000,00 динара.

Табела 1: Оgобрен буиети за библиойеку и библиобус 2010-2019

\begin{tabular}{|c|c|c|c|}
\hline Година & Библиотека & Библиобус & Укупно \\
\hline 2010 & $143.255,00$ & $69.644,00$ & $212.899,00$ \\
\hline 2011 & $410.678,00$ & $199.653,00$ & $610.331,00$ \\
\hline 2012 & $370.253,00$ & $180.000,00$ & $550.253,00$ \\
\hline 2013 & $375.000,00$ & $180.000,00$ & $555.000,00$ \\
\hline 2014 & $493.670,00$ & $240.000,00$ & $733.670,00$ \\
\hline 2015 & $464.474,00$ & $165.385,00$ & $629.859,00$ \\
\hline 2016 & $406.414,45$ & $144.711,52$ & $551.125,97$ \\
\hline 2017 & $259.315,14$ & $44.621,34$ & $303.936,48$ \\
\hline 2018 & $215.115,38$ & $32.341,00$ & $247.456,38$ \\
\hline 2019 & $243.661,56$ & $2.424,03$ & $246.085,59$ \\
\hline
\end{tabular}

Евидентно је да се након извршене категоризације јавних библиотека у шест група потпуно неједнако одређују средства за откуп публикација, а посебно је негативно то што све јавне библиотеке, без обзира на то колико им је укупно средстава намењено, добијају апсолутно иста обавезна издања, тј. у истом износу, а не сразмерно средствима која су им одобрена. Било би једино исправно да за сваку библиотеку, у односу на одобрени буџет, буде процентуално иста заступљеност обавезних наслова, а не да је неким библиотекама то скоро 100\%, а некима мање од 20\%. То доводи до ситуације у којој су мање библиотеке онемогућене да самостално изаберу књиге за своје кориснике, односно књиге које ће бити у складу са фондом који поседују. И уз прихватање става да откуп публикација не би требало да представља само попуњавање библиотечких фондова, већ промовисање вредних и квалитетних издања из претходне године, односно да се тако афирмише културна политика земље, треба имати у виду да је за многе библиотеке то једини, или, пак, значајан, начин набавке нових књига. 


\section{Обавезни наслови}

У години када смо први пут добили књиге из откупа Министарства културе и информисања Републике Србије и за библиобус (2010. године), имали смо нешто мањи износ за избор књига, па је укупно изабрано свега 128 наслова за библиобус, док је наредних година тај број био много већи 2014. године износио је 557! За ових десет година укупан број наслова које смо добили захваљујући откупу публикација јесте врло импозантан - реч је о непуних девет и по хиљада наслова, од којих је библиотека добила тачно 6.001 наслов а библиобус 3.465 .

Табела 2: Број изабраних наслова (и обавезних наслова оg 2017. їоg.) 2010-2019

\begin{tabular}{|c|c|c|c|c|c|}
\hline \multirow[b]{2}{*}{ Година } & \multicolumn{2}{|c|}{ Библиотека } & \multicolumn{2}{|c|}{ Библиобус } & \multirow{2}{*}{ Укупно } \\
\hline & $\begin{array}{c}\text { Обавезни } \\
\text { наслови }\end{array}$ & $\begin{array}{c}\text { Наручени } \\
\text { наслови }\end{array}$ & $\begin{array}{c}\text { Обавезни } \\
\text { наслови }\end{array}$ & $\begin{array}{c}\text { Наручени } \\
\text { наслови }\end{array}$ & \\
\hline \multirow{2}{*}{2019} & \multicolumn{2}{|c|}{532} & \multicolumn{2}{|c|}{227} & \multirow{2}{*}{759} \\
\hline & 221 & 311 & 221 & 6 & \\
\hline \multirow{2}{*}{2018} & \multicolumn{2}{|c|}{579} & \multicolumn{2}{|c|}{315} & \multirow{2}{*}{894} \\
\hline & 254 & 325 & 254 & 61 & \\
\hline \multirow{2}{*}{2017} & \multicolumn{2}{|c|}{617} & \multicolumn{2}{|c|}{311} & \multirow{2}{*}{928} \\
\hline & 204 & 413 & 204 & 107 & \\
\hline 2016 & \multicolumn{2}{|c|}{634} & \multicolumn{2}{|c|}{343} & 977 \\
\hline 2015 & \multicolumn{2}{|c|}{783} & \multicolumn{2}{|c|}{381} & 1.164 \\
\hline 2014 & \multicolumn{2}{|c|}{764} & \multicolumn{2}{|c|}{557} & 1.321 \\
\hline 2013 & \multicolumn{2}{|c|}{563} & \multicolumn{2}{|c|}{375} & 938 \\
\hline 2012 & \multicolumn{2}{|c|}{673} & \multicolumn{2}{|c|}{376} & 1.049 \\
\hline 2011 & \multicolumn{2}{|c|}{687} & \multicolumn{2}{|c|}{452} & 1.139 \\
\hline 2010 & \multicolumn{2}{|c|}{169} & \multicolumn{2}{|c|}{128} & 297 \\
\hline Укупно & \multicolumn{2}{|c|}{6.001} & \multicolumn{2}{|c|}{3.465} & 9.466 \\
\hline
\end{tabular}

Не залазећи у структуру обавезних наслова које је одабрала стручна комисија, треба указати на нашу ситуацију: поред тога што библиобус, као и све врсте покретних библиотека, првенствено има ограничен простор 
за смештај књига, скоро сви корисници нашег библиобуса јесу деца до 14 година, па би требало да је и библиотечка грађа у библиобусу таква да задовољава њихове потребе, односно да обухвата претежно дечју литературу.

Све до 2017. године, до када смо имали могућност самосталног одлучивања и избора наслова, откуп публикација је значајно доприносио квалитету књижног фонда библиобуса у смислу да је био у складу с потражњом корисника и њиховим читалачким интересовањима, а допринео је и повећању статистичких показатеља позајмљене грађе, тј. већем броју позајмица добијених књига. С аспекта библиотеке и библиобуса, као и њихових корисника, овакав откуп био је врло делотворан и успешан. Значили су нам и потпуно одговарали нашим потребама и откупи публикација 2015. и 2016. године, када је стручна комисија у оквиру свог избора издвојила одређене публикације сматрајући да су вредне посебне пажње и обележила их звездицом. За библиотеку смо већину тих публикација тада и наручили (осим оних наслова које смо пре тога набавили), док је за библиобус изабрано само оно што је процењено да одговара специфичној структури корисника. Али, ове публикације нису биле обавезне!

Од 2017. године наслове вредне пажње стручна комисија обележила је „звездицом”, и тако их означила као обавезне за све библиотеке, па и библиобусе, што значи да смо ми све обавезне наслове добијали у по два примерка. На тај начин почеле су да нам се гомилају књиге за одрасле које нису имале своје кориснике у библиобусу као специфичној средини с одређеним узрастом корисника. Овогодишњи откуп, односно публикације које смо добили, корисницима покретне библиотеке нису одговарале, јер су све то књиге за одрасле које углавном стоје на полицама, ретко ко их позајмљује, а након неког времена се склањају, односно замењују новим књигама и њихов употреба занемарљива је или је, пак, уопште нема. Све док смо били у могућности да самостално бирамо књиге наш избор су, наравно у много мањој мери, поред актуелних наслова домаће и стране књижевности, углавном биле књиге за децу (ако занемаримо период када смо били у обавези да из сваке понуђене групе одаберемо барем по један наслов). Ове године ми смо одабрали шест дечјих наслова (толико је било могуће у односу на одобрени буџет), а комисија је издвојила, односно обележила звездицом, још 11 наслова за децу. То значи да смо овогодишњим откупом публикација, ако изузмемо поједине публикације за одрасле, увећали активни фонд библиобуса за 17 дечјих наслова (књига). А претходних година, број дечјих књига, приновљених у фонду библиобуса захваљујући откупу, био је много већи и износио је 417. 
Грабички ирриказ уйисаних кюиїа за библиобус (за gеиу и оgрасле) из ойкуй $2010-2019$

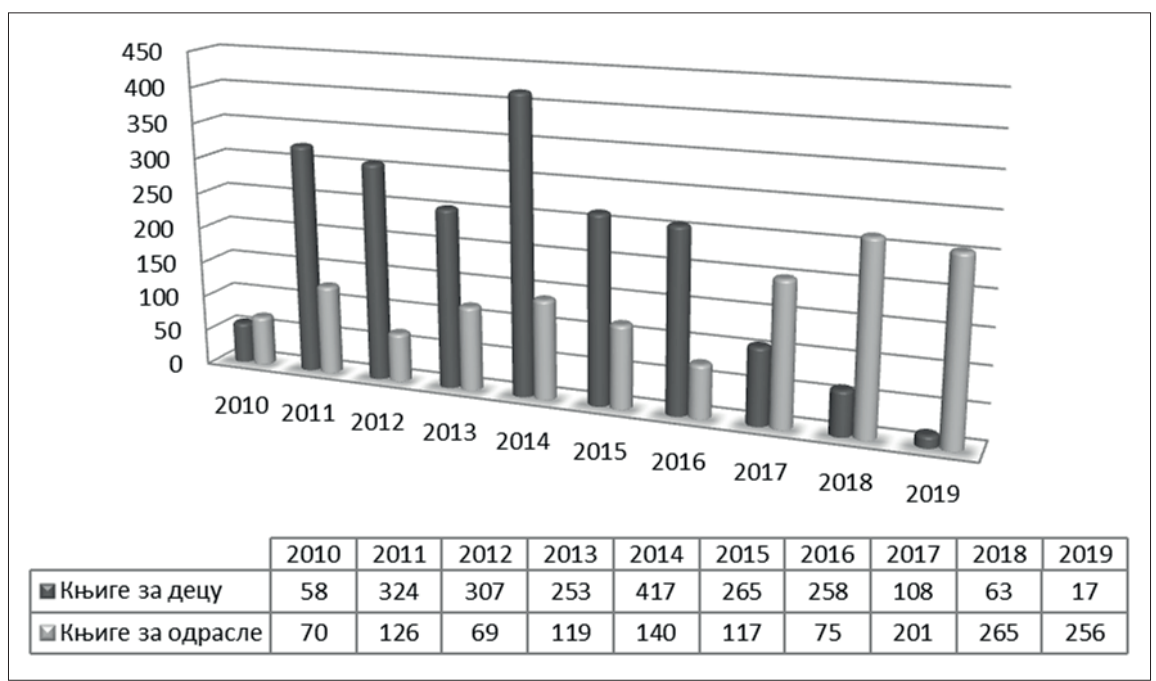

\section{Нека општа питања и примедбе на овогодишњи откуп}

Да ли су издавачи обавезни да пошаљу књиге објављене оне године са којом су конкурисали или да ли је у реду да шаљу старија издања? Добијамо издања која нису из претходне године, односно године с којом су издавачи конкурисали, већ примерке из њихових магацина. Примера ради, ове године смо добили књигу из 2007. године, то је Монйажа Владимира Волкова (Центар за изучавање традиције Укронија), књигу из 2011, Вечитиа

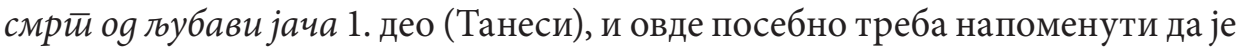
реч о књигама (и 1. и 2. део) које су поново штампане 2018. године и означене „звездицом” као обавезни наслови, иако су се исте књиге већ нашле у откупу публикација 2012. и 2013. г. када их је наша библиотека и набавила, затим 1. и 2. део наслова из 2016. г. Ошитроумни йлемић Дон Кихой оg Манче Мигела де Сервантеса (Нова књига плус).

Зашто комисија више пута исте наслове означава „звездицом”, односно зашто у обавезне наслове ставља издања која нису прва? Велики проблем представљају књиге са „звездицом”, а које су друга или трећа издања, односно дешава се да су исте књиге, тј. наслови, обележени звездицом и већ други пут обавезни за све библиотеке. Књига Цийела на крају 
светиа Дејана Алексића у издању Креативног центра први пут је била на списку откупа књига 2015. г. (прво издање наведене књиге објављено је 2014), које смо ми тада наручили и за библиотеку и за библиобус. Друго издање је објављено 2016. г. и на списку откупа 2017. г. први пут је означено звездицом, односно одређено као обавезно, тако да смо ми добили још два примерка (и за библиотеку и за библиобус), а потом је у овогодишњем откупу и треће издање наведене књиге које је објављено 2018. г. добило „звездицу” и поново смо добили још два примерка. Превид или намера?! Навешћу још неколико примера са „звездицом” за поновљена издања (по други пут су обавезни за све), а некако ми се чини да је апсолутно било довољно само их уврстити у шири избор: Кюижевносй и коментиари Слободана Владушића, Писма о gобром и лейом Димитрија Лихачева, Бранко Ћойuћ: „Кујем своју жииу” (издања Службеног гласника), као и Чуgна кюиіа Енеса Халиловића (Албатрос плус).

Што се тиче обавезних наслова који нису прва издања, многе библиотеке, а да ли је реч о већини не може се са сигурношћу рећи, у свом фонду већ поседују прва издања, па су им сада наметнута и друга издања (чак и шесто, односно седмо издање!?). Конкретно: књига, која је већ била понуђена у откупу из 2016. г. и коју је могао набавити ко год је сматрао да му је потребна, Нешйо лейо Слободана Стојановића (издавач РТС), сада је у овогодишњем откупу била обавезна и ми смо добили шесто издање за библиобус, а седмо за библиотеку, а претходно смо већ имали довољан број примерака исте књиге јер смо је и са̂ми набавили, сматрајући је корисном за фонд. Друго издање књиге Четиири луgила Милоша Латиновића (Вулкан), такође је било обавезно, а ми у свом фонду већ имамо прво издање из 2017. године, које је, такође, било у откупу 2018. г. Слично се догодило и са књигом Марине Абрамовић Пролазим кроз зиgове, која је ове године добила „звездицу”, а реч је о другом издању, иако ми у свом фонду већ имамо прво издање из 2017. године.

У априлу ове године обрадовао нас је поклон Министарства културе и информисања Републике Србије, када смо добили комплет од 15 књига

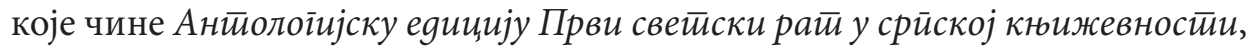
а који представља капитални издавачки пројекат Службеног гласника. Ми смо добили два комплета књига - и за библиотеку и за библиобус. И то је било одлично! Једини је проблем што смо сада добили још два комплета, јер је издање у овом откупу, очекивано, добило „звездицу”, тако да ми сада у фонду имамо четири комплета наведене едиције, тј. по два за библиотеку и два за библиобус. С обзиром на то да едиција не подразумева неке нове књиге, први пут штампане, већ су све то прештампане књиге Добрице 
Ћосића, Стевана Јаковљевића, Растка Петровића, Драгише Васића и др., ми смо их већ поседовали у свом фонду и то од различитих издавача и у више издања, а сада смо их поново добили. Мислим да би било боље да, због претходно већ добијене едиције на поклон, сада те књиге нису биле обележене звездицом; било би сасвим довољно да буду понуђене у оквиру ширег избора, па ко сматра да су му потребни додатни примерци, може да их наручи, а коме је довољан један комплет, не мора затрпавати свој фонд, поготово фонд библиобуса. Није мање важно ни то што новчана средства издвојена за наведену едицију нису уопште мала, па смо, уместо тих књига које већ имамо, могли изабрати неке друге.

Оно што је такође било занимљиво у последњем откупу, превасходно због наше минималне могућности избора књига за библиобус, јесте износ најскупљих наслова. За пет најскупљих наслова обавезних примерака (засебних књига, комплета књига или антологијских едиција), односно појединачних ставки са списка откупљених публикација, чија се цена кретала у распону од 5.280,00 до 7.920,00 динара, укупни износ је 32.184,00 динара. Ако претпоставимо да је просечна цена једне дечје књиге 500,00 динара, а можда и мање, за тај новац могли смо изабрати 65 књига за децу, које би корисници библиобуса свакако користили.

Треба овде навести и проблем који нам се дешава сваке године а то је ситуација у којој нам дистрибутер брзом поштом испоручи књиге од десетак или више издавача, са отпремницама које морамо одмах да потпишемо и оверимо без претходне провере послатих књига, па онда накнадно утврдимо да неке од њих недостају. Тада морамо да контактирамо дистрибутере, јер нас издавачи обавесте да они не сносе одговорност за књиге које недостају, већ искључиво дистрибутери, и захтевамо да нам накнадно пошаљу књиге, а то понекад буде успешно а понекад не, што значи да нам се дешава да останемо без одређених књига, које смо претходно већ евидентирали као примљене. И кад сам већ споменула издаваче, навела бих и да се ове године први пут десило да је, у директном контакту с малом издавачком кућом из Крагујевца, након констатације да нам нису испоручили наслов који смо одабрали, као и питања да ли ће то учинити ускоро, речено да они ове године нису у моїућносии и да библиотекама испоруче одабрани наслов, а притом, тај наслов је и једини са којим су конкурисали. Поставља се питање зашто су онда уопште и конкурисали?! 


\section{Закључак}

Уназад већ неколико година водила се јавна полемика у медијима око откупа публикација. С једне стране имали смо издаваче који су изражавали озбиљне замерке на набавну политику коју спроводе библиотеке јер су по њиховом мишљењу занемаривале уметнички вредна и стручна дела, а бирали комерцијална издања или „лаку” литературу. С друге стране, имали смо библиотеке и библиотекаре који су тежили да избором публикација одговоре на све захтеве својих корисника, да омогуће слободан приступ свим областима знања и да све потребне информације буду одмах на располагању, при томе не дискриминишући читалачки укус најшире публике, односно не тежећи искључиво ка књижевности високог домета.

С увођењем обавезних наслова, библиотекарима је делимично или у целости ускраћена могућност самосталног избора књига. За велике библиотеке које имају већи буџет то је изражено у мањем обиму, док је у мањим библиотекама и библиобусима ове године потпуно укинут самостални избор. Притом су намейнуйе књиге сасвим сигурно врло квалитетне, али су у већем делу, конкретно с аспекта корисника библиобуса, њима незанимљиве и не позајмљују се, већ се само гомилају на полицама или одлажу у кутије. Нису им занимљиве из простог разлога, што се мора стално понављати, зато што су корисници наше покретне библиотеке деца, па је и потребна она литература која одговара дечјем узрасту. То не значи истовремено да се преферира стручна литература или она која то није, већ су потребне оне књиге које сврставамо у књижевност за децу и младе. А ове године у откупу је број таквих књига био занемарљив. Самим тим, не верујем да је сврха нашег откупа испуњена, јер књиге које нико не чита су нам ипак бескорисне и непотребне.

Посматрано с аспекта библиотечке струке, најбоље би било омогућити нам потпуно самосталан избор наслова, јер смо једино ми библиотекари упознати како са читалачким потребама својих корисника, тако и са стањем свог фонда (посебно с већ обављеном набавком књига у претходној години), чиме бисмо спречили гомилање неодговарајуће, односно већ набављене грађе. Друго решење које би могло допринети већој успешности откупа, а притом могло бити и одговарајуће за све актере у процесу селекције наслова, јесте првенствено саветодавна улога комисије која својим предлозима помаже библиотекарима и олакшава избор књига, односно онај модел откупа по коме стручна комисија издваја и обележава звездицом све оне наслове вредне посебне пажње, али без обавезујућег услова. 
Сматрам, као библиотекар из једне мале средине, али истовремено и из библиотеке, једне од свега четири у Србији, која се може похвалити да у свом саставу поседује библиобус, да је потребно више рада на развијању узајамног поверења и међусобне комуникације свих учесника у откупу публикација, али да је првенствено потребно допустити нам да, зарад бољег и ефикаснијег откупа, а у складу с нашим потребама, сами бирамо наслове за наше кориснике, односно да би ипак требало имати вере у нас библиотекаре, као и у нашу стручност и знање.

\section{Literatura:}

1. Brofi, Piter. Biblioteka u dvadeset prvom veku. Beograd: Clio, 2005.

2. Klejton, Piter i Gari Judžin Gorman. Upravljanje izvorima informacija u bibliotekama. Beograd: Clio, 2003.

3. „Nabavna politika biblioteka i sprovođenje otkupa publikacija za biblioteke Ministarstva kulture i informisanja Republike Srbije". Čitalište god. 14, br. 27 (2015): 41-59. (na ćirilici)

4. Perunović, Nevenka. Principi nabavne politike u bibliotekama. Beograd: Zadužbina Andrejević, 1997.

5. Stokić Simončić, Gordana. „Biblioteke i izdavači”. Čitalište god. 14, br. 27 (2015): 1. (na ćirilici)

6. Trailović, Goran i Dragana Sabovljev. „Biblioteke i izdavači: Tačka Omega”. Čitalište god. 14, br. 27 (2015): 16-40. (na ćirilici) 


\author{
Sabina Đurkić \\ sabina.djurkic@gmail.com \\ Library "Cultural Centre” Kladovo
}

\title{
THE PURCHASE OF BOOKS FOR LIBRARIES IN DISCREPANCY WITH SMALL LIBRARIES USERS' NEEDS
}

\begin{abstract}
The library in Kladovo is among only four Serbian libraries that include mobile library (in a bus) known as bibliobus. Kladovo's bibliobus has been operating since 2010, and $95 \%$ of its users are children under the age of 14 , so that the most used and the most needed library material is children's literature. The purchase of publications for libraries by the Ministry of Culture and Information of Republic of Serbia used to be a very significant means of books acquisition for bibliobus users, but this year it has not been the case. Only $1 \%$ of the budget allocated to the library has been allotted to its bibliobus, instead of up to $50 \%$ as in previous years. In 2019, only 6 books were actually ordered for the bibliobus, and all the other purchased books were obligatory, not chosen by librarians. Thus, the paper shows why the current model of purchase is absolutely inconvenient for smaller libraries and bibliobuses. The author thinks that if librarians could freely choose the titles for their libraries, with the Comission in the advisory role, the purchase of publications for libraries would be better and more effective.
\end{abstract}

Keywords: public library, mobile library (bibliobus), library users, the purchase of books for libraries, obligatory titles.

Примљено: 23. октобра 2019.

Прихваћено: 12. новембра 2019. 